\title{
触 New Disease Reports \\ First report of a wilt disease of Tectona grandis caused by Thielaviopsis basicola in Brazil
}

R.C.F. Borges ${ }^{1}$, M.D.M. Santos ${ }^{2}$, M.A. Macedo ${ }^{1}$, I. Martins ${ }^{2}$, A.G. Nascimento ${ }^{3}$, L.S. Boiteux ${ }^{4}$, M.E.N. Fonseca ${ }^{4}$ and S.C.M. Mello ${ }^{2}$

${ }^{1}$ Departamento de Fitopatologia, Universidade de Brasília, 70910-900, Brasília-DF, Brazil; ${ }^{2}$ Embrapa Recursos Genéticos e Biotecnologia, CP 02372, 70770-900, Brasília-DF, Brazil; ${ }^{3}$ Floresteca, 78470-000, Rosário Oeste-Bauxi-MT, Brazil; ${ }^{4}$

Embrapa Hortaliças, CP 218, 70359-970 Brasília-DF, Brazil

*E-mail: rafaelafal@hotmail.com

Received: 19 Jun 2014. Published: 05 Oct 2014.

Tectona grandis (teak) was successfully introduced in the Midwestern region of Brazil in the early 1970s and nowadays is an important commercial timber crop in the country. Mature teak trees with wilt symptoms were observed during field surveys in commercial plantations in Mirassol do Oeste, Mato Grosso State, Brazil. Symptom-bearing vascular tissue fragments (Fig. 1) were placed on sterile carrot slices in order to allow fungal growth on this substrate. The fungal isolates from teak were then incubated under a photoperiod of 12 hours (approx. $25^{\circ} \mathrm{C}$ ). Profuse, dark-pigmented fungal growth was observed. Mycelial segments were then transferred to malt extract agar (MEA). On phase-contrast and scanning electron microscopy examination of mycelium from the MEA cultures, two types of spores were identified (Fig. 2): cylindrical, thin-walled phialospores $(10-15 \times 3-7 \mu \mathrm{m})$ produced within long tubular conidiogenous cells and thick-walled, catenulate, dark 2-6 septate chlamydospores (20-50 x 9-14 $\mu \mathrm{m}$ ). Phialides ranged from 100-170 x 5-10 um (Fig. 2). These morphological features were in accordance with those described for isolates of Thielaviopsis basicola (Berk. \& Br.), the anamorph of Ceratocystis, reported to cause wilt in teak in Brazil (Firmino et al., 2012).

Molecular analysis of the ITS1-5.8S-ITS2 rDNA region (White et al.) was carried out to confirm the morphological diagnosis. Sequence analysis of this genomic region of the Brazilian T. basicola isolate from teak (GenBank Accession No. KJ956786) indicated close identify (98-100\%) with $T$. basicola isolates from Italy (GQ131877 and GQ131525), Canada (DQ318204), China (KC191756), and Australia (HM031125; Coumans et al., 2011). Koch's postulates were fulfilled under greenhouse conditions using an inoculation methodology essentially as described by Silveira et al. (2006). One T. basicola isolate obtained under field conditions was inoculated into elite teak 'clone $\mathrm{A}^{\prime}$ (180 days after transplantation) by placing MEA-grown mycelial plugs ( $2 \mathrm{~mm}$ in diameter) in artificially-made wounds $(2 \mathrm{~cm}$ diameter) and in the vascular cambium tissue $(5 \mathrm{~cm}$ above the crown region). The vascular cambium of the control plants were inoculated with sterile MEA plugs. The fungus was re-isolated 90 days after inoculation from vascular cambium lesions from plants displaying wilt symptoms, thus confirming the pathogenicity of this isolate to teak. To our knowledge, this is the first report of T. basicola infecting teak in Brazil. Therefore, the present report is an important piece of information in order to establish pre-emptive disease management strategies under Brazilian conditions.

\section{References}

Coumans JVF, Harvey J, Backhouse D, Poljak A, Raftery MJ, Nehl D, Katz ME, Pereg L, 2011. Proteomic assessment of host-associated microevolution in the fungus Thielaviopsis basicola. Environmental Microbiology 13, 576-588. http://dx.doi.org/10.1111/j.1462-2920.2010.02358.x

Firmino AC, Tozze Jr HJ, Furtado EL, 2012. First report of Ceratocystis fimbriata causing wilt in Tectona grandis in Brazil. New Disease Reports 25, 24. http://dx.doi.org/10.5197/j.2044-0588.2012.025.024

Silveira SF, Harrington TC, Mussi-Dias V, Engelbrecht CJB, Alfenas AC, Silva CR, 2006. Annona squamosa, a new host of Ceratocystis fimbriata. Fitopatologia Brasileira 31, 394-397. http://dx.doi.org/10.1590/S0100-41582006000400010

White TJ, Bruns T, Lee S, Taylor J, 1990. Amplification and direct sequencing of fungal ribosomal genes for phylogenetics. In: Innis MA, Gelfand DH, Shinsky J, White TJ, eds. PCR protocols. A guide to methods and applications. San Diego, CA, USA: Academic Press, 315-322.
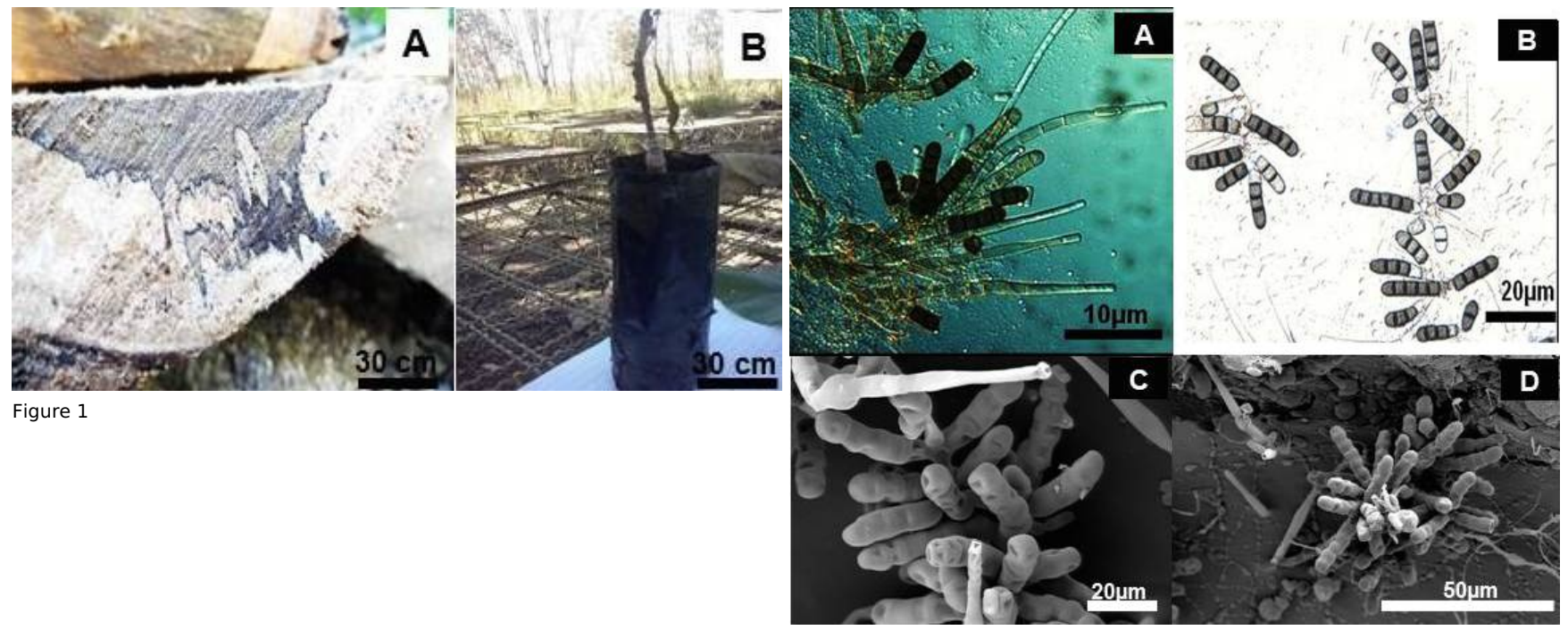

Figure 1

Figure 2

To cite this report: Borges RCF, Santos MDM, Macedo MA, Martins I, Nascimento AG, Boiteux LS, Fonseca MEN, Mello SCM, 2014. First report of a wilt disease of Tectona grandis caused by Thielaviopsis basicola in Brazil. New Disease Reports $\mathbf{3 0}, 17$. http://dx.doi.org/10.5197/j.2044-0588.2014.030.017 (C) 2014 The Authors 